\title{
Citizen Relationship Management (CiRM): the past, present, and future of an emerging concept
}

\author{
GISELA DEMO ${ }^{1}$ \\ JÚLIO MEDEIROS ${ }^{1}$ \\ FERNANDA SCUSSEL ${ }^{2}$ \\ ${ }^{1}$ UNIVERSIDAdE DE BRASílIA (UNB), BRASíLIA - DF, BRAZIL \\ 2 Universidade FEDERAL de SANTA CATARINA (UFSC), FLoRIANÓPolis - SC, BRAZIL
}

Daniel Carvalho ${ }^{1}$

\begin{abstract}
Although Citizen Relationship Management (CiRM) has been adopted worldwide to enhance the relationship between governments and citizens, little is known about the scientific field of CiRM. This article uses a literature review to analyze the scientific field of CiRM to understand its intellectual structure and set a research agenda. We analyzed 24 articles published from 2005 to 2020 , revealing that CiRM is an emergent concept in scientific literature, context-dependent, and divided into three categories: the development of integrative models; the relationship between government and citizens; and the evaluation of public services. Research on CiRM is predominantly empirical, lacking the conceptual maturity that enables contributive theoretical and empirical developments. We propose a research agenda addressing the main gaps: adoption, implementation, and efficiency of CiRM strategies, as well as the integration of such strategies in different government levels. This is the first comprehensive review about CiRM, shedding light on the knowledge of CiRM, understanding its past, and the current panorama. We contribute to the development of CiRM knowledge, guiding the researchers' efforts in the fields of relationship between governments and citizens; CiRM adoption and implementation processes; public managerial practice; and efficiency in public service provision.
\end{abstract}

Keywords: Citizen Relationship Management. Public Sector Management. Literature Review.

\section{Citizen Relationship Management (CiRM): passado, presente e futuro de um conceito emergente}

\section{Resumo}

Embora o Citizen Relationship Management (CiRM) tenha sido adotado mundialmente para aprimorar o relacionamento entre governos e cidadãos, pouco se sabe sobre o campo científico do CiRM. Este artigo relata uma revisão de literatura com o objetivo principal de analisar o campo científico do CiRM a fim de compreender sua estrutura intelectual e propor uma agenda de pesquisa. Analisamos 24 artigos publicados no período de 2005 a 2020, revelando que o CiRM é um conceito emergente na literatura científica, dependente do contexto e dividido em três categorias: o desenvolvimento de modelos integrativos; a relação entre governo e cidadãos; e a avaliação dos serviços públicos. A pesquisa sobre CiRM é predominantemente empírica, carecendo de maturidade conceitual que possibilite desenvolvimentos teóricos e empíricos contributivos. Com base nisso, propomos uma agenda de pesquisas abordando as principais lacunas: adoção, implementação e eficiência das estratégias de CiRM, além da integração dessas estratégias nos diferentes níveis de governo. Esta é a primeira revisão abrangente sobre CiRM, lançando luz sobre as bases do conhecimento de CiRM, compreendendo seu passado e o panorama atual. A partir disso, contribuímos com o desenvolvimento do corpo de conhecimento do CiRM, orientando os esforços de pesquisadores nas áreas de relacionamento entre governos e cidadãos; processos de adoção e implementação de CiRM; práticas de gestão pública; e eficiência na prestação de serviços públicos.

Palavras-chave: Gestão do Relacionamento com o Cidadão. Gestão do Serviço Público. Revisão de Literatura.

\section{Citizen Relationship Management (CiRM): pasado, presente y futuro de un concepto emergente}

\section{Resumen}

Aunque el Citizen Relationship Management (CiRM) ha sido adoptado en todo el mundo para mejorar la relación entre gobiernos y ciudadanos, se sabe poco sobre el campo científico del CiRM. Este artículo reporta una revisión de la literatura con el objetivo principal de analizar el campo científico del CiRM para comprender su estructura intelectual y establecer una agenda de investigación. Analizamos 24 artículos, publicados entre 2005 y 2020, que revelan que el CiRM es un concepto emergente en la literatura científica, dependiente del contexto y dividido en tres categorías: el desarrollo de modelos integradores; la relación entre gobierno y ciudadanos; y la evaluación de los servicios públicos. La investigación sobre CiRM es predominantemente empírica y carece de una madurez conceptual que permita desarrollos teóricos y empíricos contribuyentes. Sobre esa base, proponemos una agenda de investigación que aborde las principales brechas: adopción, implementación y eficiencia de las estrategias del CiRM, además de la integración de dichas estrategias en los diferentes niveles de gobierno. Esta es la primera revisión integral sobre CiRM que arroja luz sobre sus bases de conocimiento y entiende su pasado y el panorama actual. A partir de esto, contribuimos con el desarrollo del cuerpo de conocimiento del CiRM, orientando los esfuerzos de los investigadores en los campos de relación entre gobiernos y ciudadanos; procesos de adopción e implementación de CiRM; prácticas de gestión pública; y eficiencia en la prestación de servicios públicos.

Palabras clave: Gestión de relaciones ciudadanas. Gestión de servicios públicos. Revisión de literatura. 


\section{INTRODUCTION}

The emergence of New Public Management, which has changed the dynamic of public service provision, based on the Bureaucratic Model limitations and succesfull implemented in the Great-Britain, United States, Australia and New Zealand (Abrucio, 2007), new routes for the development of a strategic public management have been created. By that time, two major concerns guided the transformations in the public sector, pushing governments to redefine their duties worldwide: the crisis on the role of the State in the 1980s and the globalization of the economy (Bresser-Pereira, 1996; Lara \& Gosling, 2016a).

Since then, the world went through several administrative reforms that gave rise to new discourses and practices inspired in the private sector, which became benchmark for public institutions in different government levels. In this sense, the Public Administration started implementing productivity mechanisms, service-oriented actions, administrative descentralization, efficiency on service delivery, service improvement, marketization and accountability (Secchi, 2009). These are efforts to simplify the access to information and public services offered to citizens, enterprises and public employees, improving service quality and generating costs reduction (Lara \& Gosling, 2016a; Ponte, 2015).

This scenario started to be scientifically investigated, engendering the concept of Citizen Relationship Management (CiRM), a managerial philosophy that represents the efforts of all levels of government in quickly and accurately answering to citizens needs, requests and inquires, promoting changes in the public sector polices, practices and procedures (Shaikh \& Khan, 2014).

The roots of CiRM is Customer Relationship Management (CRM), a business philosophy that arise in the 1990's to establish, maintain and enhance relationships between customers and organizations by integrating technology, people and processes (Payne, 2012; Payne \& Frow, 2006). Despite the similarities between the private and public models, CRM focus on the promotion of relational benefits for companies and customers, whereas CiRM emphasizes the provision of services that are citizens' rights, contributing to the development of citizenship and the integration of society (Demo \& Pessôa, 2015; Fleury, 2005; Peci, Pieranti \& Rodrigues, 2008). Citizens are obliged, to some extent, to use services that are monopolized by governments, whereas in the private sector the goal is to maximize profits based on client's attraction and loyalty (Keramati, Saremi \& Mofrad, 2011). This means that CiRM strategies must address the complexity of the government arena, the political interests, the different timing of public practices and the increasing demands of society (Tavana, Zandi \& Katehakis, 2013). Therefore, although CiRM derives from CRM, it has its own particularities, requesting the proper analysis of its scientific field.

The purpose of CiRM is to help public managers to face the challenges regarding service provision, accountability issues and interaction with citizens, private companies and other social actors that intermediate the relationship between government and society (Larsen \& Milakovich, 2005). The idea of improving Public Administration has set a research agenda worldwide, encompassing studies on governamental ombudsman (Lara \& Gosling, 2016a); citizens satisfaction (Ghodousi, Alesheikh \& Saeidian, 2016); citizen relationship perception (Demo \& Pessôa, 2015); adoption and implementation of CiRM (Eslami, 2012; Duque, Varajão, Vitor \& Dominguez, 2013; Keramati et al., 2011); and CiRM models (Al-Khouri, 2012; Lara \& Gosling, 2016b; Pollard, Young \& Gregg, 2006).

In short, CiRM has become relevant among public organizations as an alternative to face challenges in terms of representativeness, State legitimation and in offering public services in consumer societies. However, the advances in this scientific field show difficulties in adopting and implementing CiRM (Andrade, 2013; Ponte, 2015), without a clear understanding of its conceptualization, operation and consequences, which can be justified by the innovation that CiRM means in terms of public management practices (Demo \& Pessôa, 2015). A few question rise from this discussion: how did CiRM literature ivolved during time? How is its body of knowledge currently organized? What are the paths for future of CiRM research?

We did not identify works dedicated to the comprehension of CiRM as a scientific field, which we believe to be an important step into the theoretical and empirical development of this emergent concept. Thus, this article reports a literature review with the main objective of analyzing the scientific field of Citizen Relationship Management (CiRM) in order to understand its intellectual structure and set a research agenda. According to Tranfield, Denyer and Smart (2003), literature reviews are 
an important type of study to the development of topics under the management research umbrella, since it encompasses different approaches to a synthesis, providing a broader understanding of a specific topic from the analysis of primary studies. Besides, the analysis of the intellectual structure of a certain field provides information about the most influential papers, journals, authors and emerging topics, allowing us to draw future investigation directions (Zupic \& Carter, 2015). Lastly, literature reviews are contributive to the study of emerging fields (Templier \& Paré, 2015; Zupic \& Carter, 2015), which is the case of CiRM.

To the best of our knowledge, this is the first comprehensive review about CiRM, a content of great social interest that has been rising both in public management practice and academic developments. Considering this, we shed light into the basis of the knowledge of CiRM, understanding its past and how we reached the current panorama: an emerging concept that has been undertheorized, considering the relevance of the topic for society. Most of the research on CiRM is empirical, lacking the conceptual maturity that will foster empirical developments. The comprehension of the gaps on this scientific field conducted us to the proposition of a research agenda for future investigations, contributing to the theoretical and empirical construction of this emerging concept. In addition, the results presented in this paper work as a diagnosis for government actors in charge of the managerial practice to explore the possibilities of relationship with citizens, increasing the value of their actions and promoting a better society.

After this introduction, we present a synthesis of the theoretical framework from which the concept of CiRM emerges, followed by the description of the methodological procedures and the findings. The next section discuss the results and proposes a research agenda. Conclusion and references close the paper.

\section{THEORETICAL FRAMEWORK}

The relationship between citizens and governments has become a strategic shift in the modern Public Administration, context in which the interaction between these social actors emerges as the vector to the better provision of public service and to achieve efficiency in public institutions (Ponte, 2015; Secchi, 2009). This change is based on a more dynamic relationship in which citizens more often provide information to the Public Administration through different channels - online platforms, call-centers and physical agencies, followed by the use of such information to develop better public service (Demo \& Pessôa, 2015; Lam, 2005; Larsen \& Milakovich, 2005; Lytras, 2006; Schellong, 2008). In this sense, Citizen Relationship Management (CiRM) emerges as a set of managerial practices focused on the development of a relationship between citizens and governments, creating relational benefits for both actors.

The adoption of private sector strategies to improve public services provision has guided the adaptation of CRM strategies to the public sector, in which CiRM arises with the objective of establishing and developing a relationship between organizations in the public management and the users of public services (Demo \& Pessôa, 2015; Kannabiran, Xavier \& Anantharaaj, 2004; Ponte, 2015). In this perspective, CiRM helps to improve service, quality in delivery, efficiency and to meet the citizen's real needs. Moreover, it contributes to promote citizenship and to improve the image/reputation of public services in general (Demo \& Pessôa, 2015; Schellong, 2008).

In the public arena, CiRM has emerged as a solution to manage the complex interactions between citizens and governments, allowing the integration of services, people, practices, processes and technologies while maintaining the purpose of social development (Kavanagh, 2007). Citizens now can interact with public agencies through different channels such as websites, service counter, mail, call centers or in-person service, where each interaction will result in different service experience. In this sense, CiRM contributes to change the self-reference approach of governments into a citizen-centered strategy (Al-Khouri, 2012; Fil'a, Schwarczová \& Mura, 2015; La Falce, De Muylder, Pressot \& Toivanen, 2015; Zamanian, Khaji \& Emamian, 2011). As the authors converge, the State pursues a holistic view of the public policy formulation cycles, in order to obtain legitimity of leaderships, efficacy results or by generating consensus in terms of government vision.

The change of the governamental approach, in which the citizen is considered a client of public services, has been pointed out as a turning point in the process of implementing CiRM in the Public Administration, although citizens have a multifaceted relationship with the government that goes beyond the idea of being a regular service consumer (Demo \& Pessôa, 2015; 
Kavanagh, 2007). This new perception towards citizens encouraged public entities to better access the service demands and to implement CiRM models to reduce operational costs, manage complaints and reduce response time. On the other side, citizens are more pro-active, demanding the quality and fast response in the public service provision (Demo \& Pessôa, 2015). Therefore, the Public Administration should be concerned about responsiveness, regularity, consistence and availability to public services in all service channels available for citizens (Fil'a et al., 2015).

In this context, the use of information technology has promoted the expansion of the interaction between governments and theirs citizens, encouraged transparency and guided public managers with information about citizens' perception regarding their relationship with the public services agencies (Demo \& Pessôa, 2015; Lara \& Gosling, 2016b, Zamanian et al., 2011). In this scenario, electronic government or e-government emerges as an important tool for the interaction between public agencies and citizens (Larsen \& Milakovich, 2005), using the internet as a paramount element in building governance (Lytras, 2006). Recent findings show that e-government is the main partner of governance and transparency, as it improves administrative efficiency, promotes ethical behavior and increases society trust and confidence in government (Twizeyimana \& Andersson, 2019).

According to Kavanagh (2007) and Ponte (2015), a successful CiRM strategy is only achieved by commited public employees in providing good service and through processes that generate public value to citizens. Ponte (2015) explains that the Public Administration should allign the strategies to the citizens' needs by integrating technological tools with organizational design and public employees. Nevertheless, implementation seems to be the critical point for CiRM, since governments are not able to provide quick answers to the demands and needs of public services (Andrade, 2013; Ponte, 2015). As proposed in Demo and Pessôa (2015), the adoption and implementation of CiRM is connected to a citizen-centric approach, just like CRM puts the client in the core of organizational strategies.

Based on this theoretical framework, we understand CiRM is a body of knowledge under construction. The CiRM literature has much to learn from the private sector practices and its successful cases, however, it is paramount to embrace the complexities of the public arena in order to guide further developments, academically and in the managerial practice.

\section{METHODOLOGICAL PROCEDURES}

We conducted a literature review following the guidance of Templier and Paré (2015) and their procedures for conducting literature reviews, divided in six activities: (i) formulating the problem, (ii) searching literature, (iii) screening for inclusion, (iv) assessing quality, (v) extracting data, and (vi) analyzing and synthesizing data.

In the first step, formulating the problem, Templier and Paré (2015) say authors must justify the need of a literature review, adress the research question and the objective of the study and inform how the study was designed. We believe the introduction of this paper fulfills the requirements regarding the research question and the objective formulation. Concerning the design of this literature review, we decided to combine two methods of analyzing secondary data, resorting to a qualitative systematic review analysis (Tranfield et al., 2003) and a bibliometric analysis (Zupic \& Carter, 2015).

According to Tranfield et al. (2003), systematic reviews help scholars to organize the knowledge about a certain topic and draw conclusions about the phenomenon. However, as the scholars explain, the qualitative nature of systematic reviews in management science is associated to a higher level of subjectivity. To avoid this bias, we combined the systematic review with the quantitative approach of bibliometric analysis and its potential to elevate the transparency and reproductibility of the review process (Zupic \& Carter, 2015). As the authors affirm, bibliometric analysis provide results based on bibliographic data from other primary studies, allowing conclusions regarding the structure of a field, its social networks and insights about major interest topics.

The second stage proposed by Templier and Paré (2015) is searching the literature. This means that before selecting the primary studies to be evaluated in the literature review, the authors must explore the literature of the field under investigation, which has been done in the introduction of this paper. This action is followed by the selection of a population of studies and the description of the search strategy, procedures and data sources. 
The collection of data was made in July 2020 in the scientific databases Web of Science and Scopus, the two most common source of bibliographic data (Chadegani et al., 2013; Zupic \& Carter, 2015). For the articles selection, the keywords "CZRM", "CiRM" and "Citizen Relationship Management" were used, with the Boolean operator "OR". The researchers opted not to limit the analysis period, since the research subject is new. The search filters used were "articles" as the type of publication, and Management, Business and Public Administration for the knowledge area.

In the screening for inclusion step, we identified 12 papers from Web of Science and 20 papers from Scopus. We analyzed the title and the abstract of the primary studies, besides the exclusion of duplicates, reaching a corpus of 24 articles. We decided to keep all the studies due to the fact that CiRM is an emerging concept. Afterwards, as proposed by Templier and Paré (2015), is assessing quality. In this sense, we dedicated ourselves to full article reading, and all the 24 papers were kept, generating the final sample of this study.

In the phase of data extraction, we accessed year of publication, authorship, journal of publication and country of publication, resorting to a bibliometric software to generate the analysis, which includes a bibliographic coupling analysis, as indicated by Zupic and Carter (2015). VOSviewer 1.6.11 was used due to its ability in providing cooperative relationships within a scientific field, enabling the elaboration of the bibliographic coupling (Van Eck \& Waltman, 2017). We also analyzed the number of citations of the papers, using data from Google Scholar in July 2020.

The final step is analyzing and synthesizing data, moment in which Templier and Paré (2015) suggest the authors to organize, compare and interpret data in order to create the contribuition of the literature to the body of knowledge under investigation.

\section{FINDINGS}

The first results concern the presentation of the 24 articles that composed our sample, summarized by Box 1 .

Box 1

Articles about CiRM

\begin{tabular}{|c|c|}
\hline Article & Reference \\
\hline Citizen Relationship Management and E-government & Larsen and Milakovich (2005) \\
\hline Integration challenges towards increasing e-government maturity & $\operatorname{Lam}(2005)$ \\
\hline $\begin{array}{l}\text { The semantic electronic government: Knowledge management for citizen } \\
\text { relationship and new assessment scenarios }\end{array}$ & Lytras (2006) \\
\hline $\begin{array}{l}\text { Reengineering municipality citizen electronic complaint system through citizen } \\
\text { relationship management }\end{array}$ & Chu et al. (2008) \\
\hline $\begin{array}{l}\text { Creating public value in e-government: A public-private-citizen collaboration } \\
\text { framework in Web } 2.0\end{array}$ & Hui and Hayllar (2010) \\
\hline $\begin{array}{l}\text { The value chain of citizen relationship management (CzRM): A framework for } \\
\text { improvement }\end{array}$ & Zamanian et al. (2011) \\
\hline $\begin{array}{l}\text { Citizen relationship management critical success factors: An empirical study of } \\
\text { municipality of Tehran }\end{array}$ & Keramati et al. (2011) \\
\hline A comprehensive conceptual framework for the E-government realization & $\begin{array}{l}\text { Dehkordi, Sarlak, Pourezzat } \\
\text { and Ghorbani (2012) }\end{array}$ \\
\hline $\begin{array}{l}\text { A study on the customer relationship management model adaptability with the } \\
\text { municipality services and duties environment }\end{array}$ & Eslami (2012) \\
\hline $\begin{array}{l}\text { A hybrid fuzzy group ANP-TOPSIS framework for assessment of e-government } \\
\text { readiness from a CiRM perspective }\end{array}$ & Tavana et al. (2013) \\
\hline Implementation of CRM systems in Portuguese Municipalities & Duque et al. (2013) \\
\hline $\begin{array}{l}\text { FTiS: A new model for effective urban management: A case study of urban } \\
\text { systems in Iran }\end{array}$ & $\begin{array}{l}\text { Akhondzadeh-Noughabi, Alizadeh, } \\
\text { Ahmadvand and Minaei-Bidgoli (2013) }\end{array}$ \\
\hline
\end{tabular}




\begin{tabular}{|c|c|}
\hline & Continuation \\
\hline $\begin{array}{l}\text { CRM in the public management: Development and validation of a Citizen } \\
\text { Relationship Scale (CiRS) }\end{array}$ & Demo and Pessôa (2015) \\
\hline $\begin{array}{l}\text { Citizen satisfaction survey as a tool of citizen relationship management of local } \\
\text { government in Slovakia }\end{array}$ & Fil'a et al. (2015) \\
\hline $\begin{array}{l}\text { Concerns Management, E-Government and E-Participation: Experiences and } \\
\text { Findings from Germany }\end{array}$ & Vaerst, Steffens and Lokaiczyk (2015) \\
\hline $\begin{array}{l}\text { Analyzing public participant data to evaluate citizen satisfaction and to prioritize } \\
\text { their needs via K-means, FCM and ICA }\end{array}$ & Ghodousi et al. (2016) \\
\hline Factor analysis that make up the ombudsman on relations with the citizen & Lara and Gosling (2016a) \\
\hline $\begin{array}{l}\text { Systems Administration in Ontology-Based Applications: The Case of Citizen } \\
\text { Relationship Management }\end{array}$ & Alexandrova et al. (2016) \\
\hline $\begin{array}{l}\text { Citizen Relationship Management System Users' Contact Channel Choices: Digital } \\
\text { Approach or Call Approach? }\end{array}$ & Wu (2017) \\
\hline $\begin{array}{l}\text { Evaluating Citizen Satisfaction and Prioritizing their Needs Based on Citizens } \\
\text { Complaint Data }\end{array}$ & $\begin{array}{l}\text { Ghodousi, Alesheikh, Saeidian, } \\
\text { Pradhan and Lee (2019) }\end{array}$ \\
\hline $\begin{array}{l}\text { Citizen Feedback and Executives Improving Government Performance Through } \\
\text { Citizen Relationship Management }\end{array}$ & Havaeji and Albadvi (2019) \\
\hline $\begin{array}{l}\text { Gamification Strengthening the Relationship Between the Government and the } \\
\text { Citizens }\end{array}$ & Wang and riyanto (2019) \\
\hline $\begin{array}{l}\text { Citizen Relationship Management CNRM to Build the Awareness of Anticorruption } \\
\text { Collaborative Governance Perspective }\end{array}$ & $\begin{array}{c}\text { Sukarno, Azizah, Nawangsari, Izaak and } \\
\text { Farida (2020) }\end{array}$ \\
\hline $\begin{array}{l}\text { Does Citizens } 311 \text { System Use Improve Satisfaction with Public Service } \\
\text { Encounterslessons for Citizen Relationship Management }\end{array}$ & Wu (2020) \\
\hline
\end{tabular}

Source: Elaborated by the authors.

The first analysis of the findings indicate that the articles Citizen Relationship Management and E-government (Larsen \& Milakovich, 2005) and Integration challenges towards increasing e-government maturity (LAM, 2005) were the seminal articles about CiRM, as they were the oldest works in this topic considering the parameters of our search.

Larsen and Milakovich (2005) discuss the introduction of CiRM in the public sphere as a strategy to repond to the demands of the population regarding higher service quality. The authors discuss the adaptation of CRM to CiRM, particularly addressing the transformation of citizens into consumers and its effects on democratic governance and public administration. They affirm this change from citizens to consumers has empowered society and represents a shift in the relationship between governments and citizens, that should be properly managed. In this context, CiRM emerges as a feasible strategy to enhance this relationship and to help public managers to face the challenges of this new and complex context.

Lam (2005) presents CiRM as an important perspective to face the challenges of government in contemporary society, shedding light into the role of e-government in fostering the relationship between governments and citizens. The author proposed a model for e-government composed by four progressive stages: (i) informational e-government, (ii) transactional e-government, (iii) process integrated e-government and (iv) service integrated e-government. The article sets a difference between e-government and CiRM, showing that e-government is a CiRM strategy that will provide better results when integrated to other CiRM practices as collaborative processes and technology integration.

The analysis of this two seminal papers justifiy one of the observations we made during the full reading of the 24 papers: there is a conceptual confusion between CiRM and e-government. CiRM is a broader concept, a holistic business philosophy brought to the public sector in order to improve the management of the relationship between governments and citizens, whereas e-government is the use on internet applications in order to provide access and delivery of government information and public services (Larsen \& Milakovich, 2005). Thus, e-government can be considered a strategy of CiRM.

Considering 2005 as the beginning of the scientific field of CiRM, the next step was to evaluate the development of the field in term of scientific production, as Figure 1 illustrates. 
Figure 1

Number of published articles on CiRM

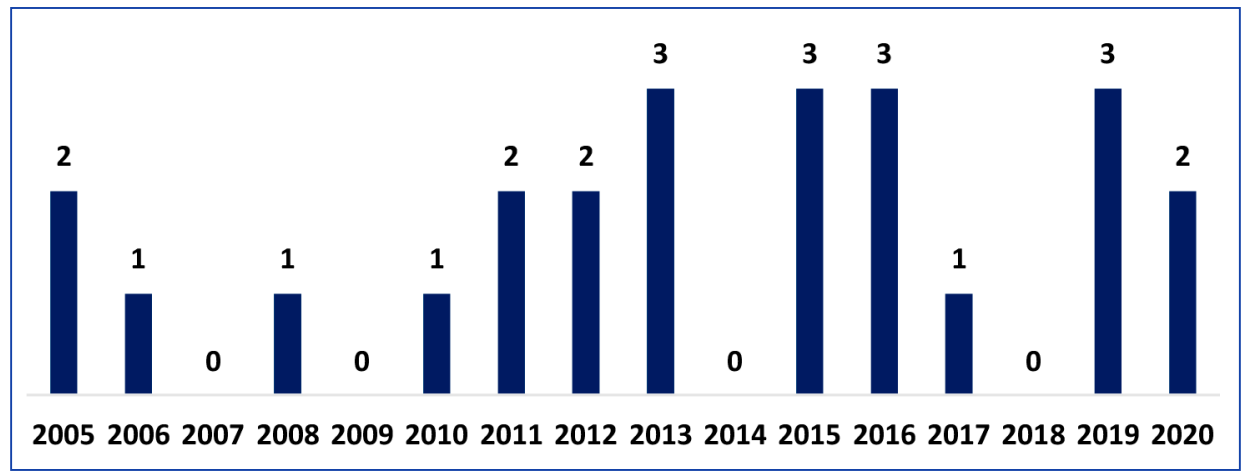

Source: Elaborated by the authors.

From 2005 to 2020, 24 articles were published in a relatively stable pattern. The years of 2013, 2015, 2016 and 2019 were the most productive years, with three papers each year. From this, we understand Citizen Relationship Management - CiRM as a subject under development, since the first publication identified was in 2005.

From the 24 papers, nine were conceptual papers and 15 were empirical research. Most of the conceptual works were dedicated to the development of frameworks to understand the role of knowledge management in the context of CiRM (Lytras, 2006), to create a model of adaptability of the public services (Eslami, 2012) and to address e-government models (Dehkordi et al., 2012; Hui \& Hayllar, 2010). The theoretical approach is also used to explore systemns administration (Alexandrova et al., 2016), to investigate the role of CiRM in anticorruption strategies (Sukarno et al., 2020) and to analyze the value chain that compose CiRM (Zamanian et al., 2011). From this, we identify a strong effort in building a CiRM framework, however, little attention is directed to conceptualizations of the construct or to the investigation of its antecedents or consequents. This could be an important theorization to validate CiRM models in empirical research.

The first empirical research identified was the work of Chu, Yeh and Chuang (2008), a case stuty in Taiwan. We also identified case studies in Germany (Vaerst et al., 2015), Iran (Akhondzadeh-Noughabi et al., 2013), Portugal (Duque et al., 2013) and Tehran (Keramati et al., 2011). Literature encompasses cluster analysis to understand citizen satisfaction (Ghodousi et al., 2016) and citizens' complaints (Ghodousi et al., 2019). We also observed surveys exploring citizen feedback about government performance (Havaeji \& Albadvi, 2019), the role of ombudsman (Lara \& Gosling, 2016a), citizen preference on digital or call approach (Wu, 2017) and citizen satisfaction (Fil'a et al., 2015; Wu, 2020). We highlight the article of Demo and Pêssoa (2015) and the proposition of the first scientific validated scale to masure citizen relationship perception, addressing the main aspects of the relationship between government and citizens.

These findings show the academic knowledge about CiRM is been built based on the need of each context of investigation, since there is no clear connection between the theme of the articles: they seam to serve to the managerial practice of the contex under investigation. We noticed that literature is still exploratory. We comprehend that CiRM is still a concept in construction, and the lack of conceptualizations and measurement instruments are the next step for the theoretical and empirical development of this emergent concept.

Next, we identified the journals that published CiRM papers during the analyzed period. This actions showed 21 journals publishing about CiRM. Considering that we have a total of 24 articles spread in 21 journals, we reinforce the idea that CiRM is a construct under development. We understand that a new topic arouses the interest of many researchers and scientific journals, justifying the lack of concentration of publications in a specific journal. The journals Australian Journal of Public Administration, Cities and Eletronic Government published 2 articles each, and the other 18 papers published one article each.

Afterwards, we identified the Top 5 most cited journals, using data from Google Scholar in July 2020. According to Zupic and Carter (2015), the number of citations are a metric of influence of a journal or a paper, indicating that the content 
from the most cited journal/article are important to the development of the knowledge in a certain field. Thus, the most influential journal on CiRM literatureis the Australian Journal of Public Administration (80 citations), followed by Eletronic Government (45 citations), Information and Management (37 citations), Cities (14 citations) and the Journal of E-Government (10 citations).

In the following, we analyzed the articles by country of the publication, in order to reveal if there was a concentration on knowledge development. Iran was the country with the highest number of published articles on CiRM (7 papers), followed by Taiwan ( 3 papers) and Brazil, China and Indonesia with 2 papers each. The other countries identified published only one paper in the analyzed period. No network of research was identified. The number of countries publishing about CiRM can be an indicator of the interest of governments in adopting and implementing CiRM strategies to face the challenges of prodiving efficient public service. This global interest, despite the lack of a structured network of research, sheds light into the fact that CiRM is a context-dependent construct. In other words, it depends on the context of analysis, the particularities of each country, state, region or city to be successful. The political scenario, the social and economic conditions, the culture and the dynamics between government, citizens and social actors must be accesses in a CiRM strategy formulation.

Next, we analyzed the most influential papers, using the criteria of number of citations (Zupic \& Carter, 2015). We accessed the number of citations in Google Scholar in July 2020.

The most cited article in CiRM literature since 2005 is Creating public value in e-government: A public-private-citizen collaboration framework in Web 2.0, written by Hui and Hayllar (2010), with 152 citations. The authors focus on the challenges faced by public managers in trying to innovate in the public service provision, context in which CiRM is seen as a tool that enables collaborative interactions between government, citizens and private stakeholders. The implementation of CiRM is connected to the increasing use of Web 2.0 in creating content for the public and service design, in an attempt to access citizen information and enhance the value of public serice delivery.

The second place in our ranking is shared by the articles Citizen Relationship Management and E-government (Larsen \& Milakovich, 2005) and A hybrid fuzzy group ANP-TOPSIS framework for assessment of e-government readiness from a CiRM perspective (Tavana et al., 2013), with 52 citations each.

The article written by Larsen and Milakovich (2005) is the seminal papers in CiRM literature and presents to public management studies an alternative brought by the private companies' context in an attempt to help publich managers to deal with he problems of the public service delivery and the demands from the society. CiRM arises as a challenge-solution alternative in the contemporary public sector scenario, being a tool to enhance communication, promote better services and reduce public costs. For its turn, the publication from Tavana et al. (2013) propose a model to access government readisness assessment, which means the ability of governments in accessing citizens' information and proposing solutions to public problems in a fast way, using the internet as the main tool.

Next, Lytras (2006) wrote The semantic electronic government: Knowledge management for citizen relationship and new assessment scenarios, in which the author theorizes CiRM as a knowledge-intensive task, based on knowledge infrastructures, knowledge flows and dynamic transformations ( 35 citations). The main purpose of the paper is to shed light into the knowledge management convergent in the adoption of CiRM. The author states that the complexity around the diversity of structures, regulations, procedures and the nature of public offer affect the dynamics of knowledge management, a paramount integration for the successful implementation of CiRM.

The fourth most cited paper is Reengineering municipality citizen electronic complaint system through citizen relationship management (Chu, Yeh \& Chuang, 2008), with 24 citations. This work emphasizes the role of e-government and its main function of enabling the interation between government and citizens. According to the authors, e-government is the main input of CiRM strategis, since is allows the communication between the actors and, from this, better understanding of citizens' demands, improved service quality and public participation.

Lastly, in CRM in the public management: Development and validation of a Citizen Relationship Scale (CiRS), Demo and Pessôa (2015) set a milestone in CiRM literature by developing and validating a scientific scale to measure the perception of citizens regarding CiRM initiatives in public management (19 citations). The scale can be used for validations in different context, 
respecting the complexity of each context, revealing the most relevant aspects in the relationship between governments and citizens. In this regard, the result from studies using the scale can be used as a diagnostic tool by public managers to promote an effective relationship management with citizens.

By analyzing the five most cited articles, there is a convergence between them regarding the challenges in replicating the private sector strategies in the complexity of governments, context formed by different structures, institutions, interests and political matters, besides the needs of the citizens and the society as a whole. We foresee, from the studies, that public managers are presenting a different posture in their actions as public employees, acting in an innovative way with the objective of providing better quality service in a reasonable time. Communication, interaction and readiness of governments are contents that permeate the most cited articles, revealing this is not only a matter of public interest, but a framework that needs further developments in the academic research.

The last step was to explore the main discussions under CiRM literature. We created a bibliographic coupling in order to address the main subfields of CiRM research. According to Zupic and Carter (2015), bibliographic coupling is a visual representation of the connection between references, used as a measure of similarity, creating clusters that bring together similar interest. Due to the low number of articles published in the analyzed period (24 papers), the bibliographic coupling considered the sharing of at least one article. We have identified three clusters, as Figure 2 illustrates.

Figure 2

\section{Bibliographic coupling}

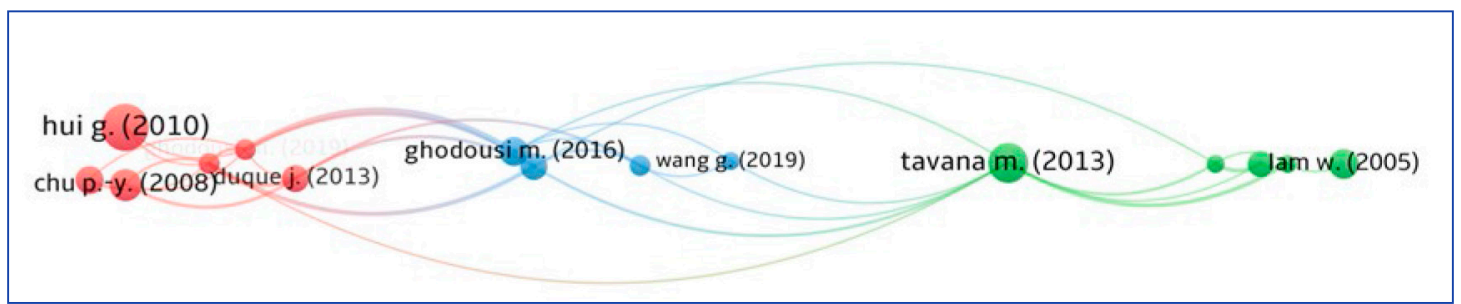

Source: Elaborated by the authors.

The green cluster is formed by articles dedicated to the creation of models and conceptual frameworks of CiRM. In this regard, Tavana et al. (2013) evaluated the availability and effectiveness of the e-government platform adopted in the state of East Virginia in the United States. Wu (2017) evaluated the expansion of the SF311 service system, which has a call center and application in the city of San Francisco in the United States. Dehkordi et al. (2012) performed a literature review to verify the theories surrounding e-government and point to the existence of a conceptual framework with the following configuration: the social/ demographic context, the creative process of elaboration public policies and the content of the electronic government bases with result and efficiency indicators. For its turn, Lam (2005) brings a study on the maturity assessment of e-government and points out that four steps are necessary to consolidate the management of the relationship with the citizen and also suggests that countries like United Kingdom and Singapore, even advanced, still have a long way to go in the challenge of integration. Thus, the green cluster encompasses efforts in integrating the structures and institutions that compose the complexity faced by public managers in public service provision.

The red cluster comprises studies that investigate the improvement of the relationship between government and citizen and the success in the use of CiRM tools. Chu et al. (2008) studied the ombudsman system for the citizens of Kaohsiung and Taiwan to demonstrate the benefits of managing CiRM in improving citizen understanding, in the quality of public services, in expanding public participation, and in strengthening control. Keramati et al. (2012) studied the critical success factors in the application of a CzRM model in the municipality of Tehran and found that these success factors are: process, organization, knowledge management and citizens' demands. Hui and Hayllar (2010) pointed to the need for genuine involvement of society in the definition of public services and suggested the use of new technological tools, in CzRM models, to increase citizen participation. Duque et al. (2013) conducts research in Portuguese municipalities that have adopted customer relationship management systems and points out that the improvement of the relationship with citizens and a higher quality of information are some of the most important results obtained by the municipalities. 
The blue cluster brings studies addressing the evaluation of public services by the citizens. Ghodousi et al. (2016) carried out a cluster analysis using telephone service 137 in Iran, and it was found that the main demands were related to the quality of asphalt, garbage collection and park development. Akhondzadeh-Noughabi et al. (2013) used the text mining technique to assess the information from the Tehran urban service complaint system, revealing that this CiRM approach is useful to improve management from the perspective of service frequency, length of service and citizen satisfaction. Demo and Pessôa (2015) developed and validated a scale of relationship with the citizen applied to the Superior Court of Justice of Brazil, unprecedented in national and international literature, filling a gap in the literature and enabling future relational studies in the areas of relationship marketing in Public Administration.

These findings show that the CiRM literature is divided in three major categories: (i) the development of integrative models and theoretical frameworks; (ii) the relationship between government and citizens and the aspects creating this relationship; and (iii) the evaluation of public services by the citizen. However, there is no overlap between clusters: it is expected that clusters are overlapped and connected. We understand this is another evidence of the inicipience of this concept. Although the seminal papers date from 2005, CiRM is still and emergent concept, a conclusion that guided us to develop a research agenda.

\section{Discussion and Research Agenda Proposition}

The findings from this literature review show that Citizen Relationship Management - CiRM is a new subject in literature, rising in 2005 from the works of Customer Relationship Management, a business philosophy dedicated to the creation of long-term relationships between organizations and customes, with the objective of adapting CRM strategies to the context of the relationships between citizens and public service providers.

The first main discussion regards the incipience of the subject in the scientific literature. When we analyze Box 1 and the articles published since the seminal works of Larsen and Milakovich (2005) and Lam (2005), we note the importance of e-government developments on CiRM research. However, we can not understand e-government and CiRM as synonims, as e-government is one of the possibilities among CiRM strategies. In this sense, we propose that future studies emphasize other CiRM strategies beyond e-governement, as well as the efficiency of such strategies and the combination between them. We also highlight the need of conceptual developments on CiRM in order to understand the nature of this construct, which certainly will contribute to the theoretical and empirical advance of this scientific field.

The second discussion to be addressed is the fact that CiRM is a context-dependent construct, meaning that not only the managerial practices in the public service but the academic research must comprise the complexity of each context. Research on CiRM must respect the particularities of each context, as different governments will develop distinct relationships with their citizens, and the management of such relationship will depend on the available resources (people, processes and technologies) and the characteristics of each culture. However, we foresee possibilities of creating models for different government levels, such as local, regional and national, to investigate how the strategies of CiRM are developed in these levels and, more importantly, if (and how) they are connected as a national government strategy. Cross-culture research can also be embraced in this context, as different locations of the globe can certainly learn from each other.

Additionally, we aim attention to the scale developed by Demo and Pessôa (2015) in the Brazilian context and its capacity of measuring citizen perception about public services. We believe this work will enable several future studies, especially relational studies and the evaluation of public service provision in different important variables such as citizens' satisfaction and public service performance, for example. Considering that CiRM is a context-dependent construct, we strongly recommend the validation of this scale to the different countries in which CiRM has been adopted and implemented, in order to embrace the complexity of each scenario and enable CiRM to fulfill its purpose of better public service provision.

Third, we analyze the streams of research that compose the CiRM scientific field. CiRM studies are distributed in three major areas: (i) conceptual frameworks and models, regading papers emphasizing the integration of the social actors and the processes generating CiRM strategies; (ii) the relationship between government and citizen through the use of CiRM tools, in reference to studies addressing the relational benefits of such relationship and the dynamics of adoption and implementation of CiRM systems; and (iii) the evaluation of public services by the citizen, with respect to the development of measurement instruments. The next step is to connect such studies, bringing together conceputalizations and empirical efforts in order to better explore adoption, implementation, antecedents, consequences and limitations of CiRM strategies. 
We also foresee possibilities around the conceptual frameworks of CiRM systems in the electronic government. An important agenda should consider CiRM not only as a electronic government tool, but also as a broader relational strategy based on the CRM concept, for the development and delivery of public services as a result of the contemporary interaction between government and citizen. In this sense, we expect future investigations to explore how the four stages of e-government maturity of Lam (2005) interact with other CiRM strategies, and how different levels of government (local, regional and national) reaches e-government maturity. Moreover, we recommend that future research pays attention to the role of digital devices in shaping this relationships, understanding the role of social media and how the development of digital channels to interact with citizens can benefit both society and public managers. The adoption, implementation and efficiency of digital communication strategies should be further explored, as well as the consequences of such efforts for the society.

Next, we add to our agenda possibilities regarding the improvement of the relationship between citizens and governments. In this perspective, we identify the need of further exploring the effects of the political system and the macro environment on CiRM strategies, respecting the idiossincracies of cultural, legal and economic aspects of each context of investigation. Although CiRM is a global concept, reflecting a global phenomenon, we must understand the macro environment but act local, adapting the strategies of CiRM to the needs of communities in terms of public services, emphasizing the most critical social demands. We also suggest to think the opportunities brought by CiRM studies to develop strategizing practices in the work environment of public organizations, to promote public empoloyees' training and education focusing on high quality public service delivery and, lastly, addressing the results of CiRM works to the formulation of public policy agenda.

In methodological terms, we ratify the need and opportunity for empirical research, resorting to multimethod studies. Such studies enable the use of triangulation for a better approach and understanding of research topics. By mixing quantitative methods and techniques to measure a phenomenom, the qualitative approaches help with interpretation, revealing important aspects not perceived only with numbers themselves.

\section{CONCLUSION}

The main objective of this paper as to analyze the scientific field of Citizen Relationship Management - CiRM in order to understand its intellectual structure and set a research agenda. The exam of 24 articles enabled to say that CiRM is an emerging concept in the scientific field, confirming the need of a literature review in order to organize past results, understand the current state of the research and set avenues for future investigations. From the analysis of the intellectual structure of CiRM literature, we were able to identify the most notable gaps and draw a research agenda, which is the main contribution of the present literature review. We expect to contribute with the development of CiRM body of knowledge, guiding the efforts of researchers in the fields of relationship between governments and citizens; CiRM adoption and implementation processes; public managerial practice; and efficiency in public service provision. We also believe that our results will help students and researchers to identify excellence centers and reference studies to develop their works and establish partnerships.

Although the present study used two important databases, one major limitation must be addressed. In this sense, we note that the CiRM production was not fully mapped. Thus, if the objective is to identify all the scientific production on CiRM, a broader research that includes other databases and proceeding papers from scientific conferences and seminars, as well as books and thesis, should be considered. Additionally, as CiRM emerges from CRM studies, we foresee the possibility of publications about the relationship between governments and citizens without the use of the CiRM term. In this regard, future research could not only explore CiRM, but also the relationship between governments and citizens, which ultimately will contribute to the CiRM development. We also suggest future literature review on CiRM in order to keep track on the subject and forthcoming research directions. 


\section{REFERENCES}

Abrucio, F. L. (2007). Trajetória recente da gestão pública brasileira: um balanço crítico e a renovação da agenda de reformas. Revista de administração pública, 41(esp), 67-86.

Akhondzadeh-Noughabi, E., Alizadeh, S., Ahmadvand, A. M., \& MinaeiBidgoli, B. (2013). FTiS: A new model for effective urban management: A case study of urban systems in Iran. Cities, 31, 394-403.

Al-Khouri, A. M. (2012). Customer relationship management: Proposed framework from a government perspective times. Journal of management and strategy, 3(4), 34.

Alexandrova, A., lordanov, B., Abbas, S., Upadrasta, P., Sarasti, M. ... Hilpold, T. (2016). Systems Administration in Ontology-Based Applications: The Case of Citizen Relationship Management. International Journal of Public Administration in the Digital Age, 3(2), 37-46.

Andrade, M. M. G. (2013). Plataforma De Relacionamento Com O Cidadão: Solução de Governança Eletrônica para a Prefeitura Municipal do Salvador. PontodeAcesso, 7(2), 68-88.

Bresser-Pereira, L. C. (1996). Da administração pública burocrática à gerencial. Revista do Serviço Público, 47(1), 1-28.

Chadegani, A., Salehi, H., Yunus, M., Farhadi, H., Fooladi, M. ... Ale Ebrahim, N. (2013). A comparison between two main academic literature collections: Web of Science and Scopus databases. Asian social science, 9(5), 18-26.

Chu, P. Y., Yeh, S. C., \& Chuang, M. C. (2008). Reengineering municipality citizen electronic complaint system through citizen relationship management. Electronic Government, 5(3), 288-309.

Dehkordi, L. F., Sarlak, M. A., Pourezzat, A. A., \& Ghorbani, A. (2012). A comprehensive conceptual framework for the e-government realization. Australian Journal of Basic and Applied Sciences, 6(8), 50-64.

Demo, G., \& Pessôa, R. (2015). CRM na administração pública: desenvolvimento e validação de uma Escala de Relacionamento com o Cidadão (ERCi). Revista de Administração Pública, 49(3), 677-697.

Duque, J., Varajão, J., Vitor, F., \& Dominguez, C. (2013). Implementation of CRM systems in Portuguese Municipalities. Local Government Studies, 39(6), 878-894.

Eslami, S. (2012). A study on the customer relationship management model adaptability with the municipality services and duties environment. International Research Journal of Finance and Economics, 82, 33-48.

Fil’a, M., Schwarczová, L., \& Mura, L. (2015). Citizen satisfaction survey as a tool of citizen relationship management of local government in Slovakia. Serbian Journal of Management, 10(1), 117-129.

Fleury, S. (2005). A seguridade social e os dilemas da inclusão social. Revista de Administração Pública, 39(3), 449-467.

Ghodousi, M., Alesheikh, A. A., \& Saeidian, B. (2016). Analyzing public participant data to evaluate citizen satisfaction and to prioritize their needs via K-means, FCM and ICA. Cities, 55, 70-81.

Ghodousi, M., Alesheikh, A. A., Saeidian, B., Pradhan, B., \& Lee, C. W. (2019). Evaluating Citizen Satisfaction and Prioritizing Their Needs Based on Citizens' Complaint Data. Sustainability, 11(17), 4595.
Gupta, G., \& Aggarwal, H. (2016). Analysing customer responses to migrate strategies in making retailing and CRM effective. International Journal of Indian Culture and Business Management, 12(1), 92-127.

Hui, G., \& Hayllar, M. R. (2010). Creating public value in e-Government: A public-private-citizen collaboration framework in Web 2.0. Australian Journal of Public Administration, 69, S120-S131.

Kannabiran, G. M. J. X., Xavier, M. J., \& Anantharaaj, A. (2004). Enabling e-governance through citizen relationship management-concept, model and applications. Journal of Services Research, 4(2), 223-240.

Kavanagh, S. C. (2007). Revolutionizing constituent relationships: The promise of CRM systems for the public sector. Chicago, IL: Government Finance Officers Association.

La Falce, J. L., De Muylder, C. F., Pressot, I. M., \& Toivanen, M. A. B. L. (2014). Qualidade no serviço Público: Um estudo de caso em uma fundação pública em Minas Gerais. Amazônia, Organizações e Sustentabilidade, 3(2), 43-62.

Lara, R. D., \& Gosling, M. S. (2016a). Análise dos fatores que compõe a ouvidoria no relacionamento com o cidadão. Revista ESPACIOS, 37(23), 23.

Lara, R. D., \& Gosling, M. S. (2016b). Um Modelo De Gestão Do Relacionamento Entre Os Cidadãos E A Administração Pública. REAd. Revista Eletrônica de Administração, 22(2), 333-362.

Larsen, B. \& Milakovich, M. (2005). In International Conference on Electronic Government (pp. 57-68). Berlin, Germany: Springer.

Lytras, M. D. (2006). The Semantic Electronic Government: knowledge management for citizen relationship and new assessment scenarios. Electronic Government, 3(1), 5-17.

Payne, A. (2006). Handbook of CRM: Achieving Excelence in Customer Relationship. Oxford, UK: Elsevier.

Payne, A., \& Frow, P. (2006). Customer relationship management: from strategy to implementation. Journal of Marketing Management, 22(12), 135-168.

Peci, A., Pieranti, O. P., \& Rodrigues, S. (2008). Governança e New Public Management: convergências e contradições no contexto brasileiro. Organizações \& Sociedade, 15(46), 39-55.

Pollard, C., Young, J., \& Gregg, P. (2006). Towards a simplified framework of CRM for use in public and private sectors. Journal of Information Technology Case and Application Research, 8(2), 24-38.

Ponte, V. (2015). CiRM: CRM no Setor Público. In G. Demo (Org.), Marketing de Relacionamento \& Comportamento do Consumidor (pp. 137-174). São Paulo, SP: Atlas.

Schellong, A. (2008). Citizen Relationship Management. A Study of CRM in Government. Bern, Switzerland: Peter Lang.

Secchi, L. (2009). Modelos organizacionais e reformas da administração pública. Revista de Administração Pública, 43(2), 347-369.

Shaikh, R., \& Khan, M. R. (2014). Citizen Relationship Management: A Decisive Parameter of G2C e-Governance Web Portals of Maharashtra India. International Journal on Recent and Innovation Trends in Computing and Communication, 2(8), 2234-2239. 
Sukarno, G., Azizah, N., Nawangsari, E. R., Izaak, W. C., \& Farida, S. N. (2020). Citizen relationship management (CnRM) to build the awareness of anti-corruption: Collaborative governance perspective. International Journal of Psychosocial Rehabilitation, 24(8), 1299-1306.

Tavana, M., Zandi, F., \& Katehakis, M. N. (2013). A hybrid fuzzy group ANP-TOPSIS framework for assessment of e-government readiness from a CiRM perspective. Information \& Management, 50(7), 383-397.

Templier, M., \& Paré, G. (2015). A framework for guiding and evaluating literature reviews. Communications of the Association for Information Systems, 37(1), 112-137.

Tranfield, D., Denyer, D., \& Smart, P. (2003). Towards a methodology for developing evidence-informed management knowledge by means of systematic review. British journal of management, 14(3), 207-222.
Twizeyimana, J. D., \& Andersson, A. (2019). The public value of E-Government-A literature review. Government Information Quarterly, 36(2), 167-178.

Vaerst, T., Steffens, T., \& Lokaiczyk, R. (2015). Concerns Management, E-Government and E-Participation: Experiences and Findings from Germany. International Journal of E-Planning Research, 4(4), 36-49.

Van Eck, N. J., \& Waltman, L. (2017). Citation-based clustering of publications using CitNetExplorer and VOSviewer. Scientometrics, 111(2), 1053-1070.

Zamanian, M., Khaji, M. R., \& Emamian, S. M. S. (2011). The value chain of citizen relationship management (CzRM): A framework for improvement. African Journal of Business Management, 5(22), 8909-8917.

Zupic, I., \& Čater, T. (2015). Bibliometric methods in management and organization. Organizational Research Methods, 18(3), 429-472.

Daniel Carvalho

ORCID: https://orcid.org/0000-0002-5307-7680

Ph.D. student in Administration from the Postgraduate Program in Administration at the University of Brasília. E-mail: danizalho@gmail.com

Gisela Demo

ORCID: https://orcid.org/0000-0003-1864-0471

Ph.D. in Social Psychology of Work and Organizations at the University of Brasilia; Professor of the Graduate Program in Administration at the University of Brasília. E-mail: giselademo@gmail.com

Júlio Medeiros

ORCID: https://orcid.org/0000-0002-1208-6740

Master of Business Administration at the University of Brasília. E-mail: julioelpidio@gmail.com

Fernanda Scussel

ORCID: https://orcid.org/0000-0001-7953-6710

Ph.D. in Administration at the Federal University of Santa Catarina. E-mail: contatofernandascussel@gmail.com 